Int. J. Dev. Biol. 54: 991-1002 (2010)

doi: $10.1387 /$ ijdb. 103065 th

\title{
Dissecting hematopoietic differentiation using the embryonic stem cell differentiation model
}

\author{
TARA L. HUBER* \\ Stem Cell and Developmental Biology Department, Genome Institute of Singapore, Singapore
}

\begin{abstract}
Embryonic stem cells (ESCs) have been successfully used to study the generation of the hematopoietic lineage. The ESC differentiation model provides access to distinct developmental stages during hematopoietic differentiation enabling us to study developmental transitions in a manner that is difficult to do with embryos. The identification of the bipotential hemangioblast/ blast-colony forming cell (BL-CFC) which represents the earliest stage of hematopoietic commitment in ESC cultures has enabled the study of signalling pathways, transcription factors and enzymes at the level of this developmental stage. Reporter ESC lines, flow cytometry and serumfree culture reagents are helping the field to transition from serum-containing protocols to stepwise serum-free differentiation strategies that attempt to mimic the developmental processes in the embryo. This serves as a framework with which to approach directed differentiation of human ESCs for the purposes of regenerative medicine. This review is focused on the contributions that the ESC differentiation system has made to understanding hematopoiesis and will highlight the strengths of this model of development and the challenges it still faces.
\end{abstract}

KEY WORDS: embryonic stem cell, hemangioblast, hemogenic endothelium, differentiation, hematopoiesis

\section{Introduction}

Developmental biology is the study of cellular decisions and molecular programs that lead to the formation of the whole organism. This body of knowledge is comprised of discoveries from a variety of model systems such as the chick, Xenopus, zebrafish and mouse. One can add to this group of vertebrate models the embryonic stem cell (ESC) differentiation system where development is studied as it occurs in vitro. ESCs are the undifferentiated, self-renewing cell lines derived from the inner cell mass of the blastocyst stage embryo (Evans and Kaufman, 1981; Martin, 1981). They have the potential to give rise to the various cell types of the organism when cultured in appropriate tissue culture conditions. The ability to access cells at different stages of development and to use a combination of genetic, molecular biology and tissue culture tools has led to a wide range of perturbations that help us understand developmental processes. This is particularly helpful to the study of human development as human ESC (hESC) differentiation cultures can serve as a powerful surrogate for human embryos.

The study of the hematopoietic system using ESCs shows the power of using this in vitro model to understand development. Tools such as in vitro and in vivo hematopoietic assays provide the functional and quantitative analysis to strengthen conclusions made from hematopoietic gene expression analysis. Flow cytometry has also been helpful not only to demonstrate the presence of hematopoietic lineages but also to follow and isolate early developmental stages. Interest in the ESC system has been greatly fuelled by its potential to supply cells for cell replacement therapy in the treatment of a wide range of diseases. This has also been heightened by the advent of induced pluripotent stem (iPS) cells where a somatic cell can be reprogrammed into an ESC-like state (Okita et al., 2007; Park et al., 2008; Takahashi et al., 2007; Takahashi and Yamanaka, 2006; Wernig et al., 2007; Yu et al., 2007). This was first demonstrated through the forced expression of Oct4, Sox2, c-Myc, and Klf4 in murine fibroblasts and now can be performed with two factors (either Oct4/KIf4 or Oct4/Sox2) and the addition of small-molecule compounds (Huangfu et al., 2008; Okita et al., 2007; Shi et al., 2008; Takahashi and Yamanaka, 2006; Wernig etal., 2007). This raises the possibility of generating patient-specific iPS cells that as with ESCs would then be differentiated towards the cell type of therapeutic interest. The hemato-

Abbreviations used in this paper: BL-CFC, blast-colony forming cell; ESC, embryonic stem cell; iPS induced pluripotent stem cell; YS, yolk sac.

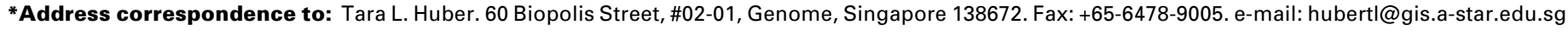
Tel: +65-6808-8169. Fax: +65-6808-8000. Web: http://www.gis.a-star.edu.sg/internet/site/investigators.php?user_id=93\&f=cv
} 
poietic system offers us a clear indication of the potential for this with the established example of hematopoietic stem cell (HSC) transplantations for the treatment of hematopoietic disorders. There is therefore an intense effort to direct ESCs towards the HSC fate. Key to the success of this is our ability to recapitulate in culture the developmental processes involved in generating functional HSCs.

\section{From gastrulation to the embryonic sites of hemato- poiesis}

Hematopoietic cells originate in multiple sites during embryogenesis: the yolk sac (YS), aorta-gonad-mesonephros (AGM) region, placenta and the vitelline and umbilical arteries (Dzierzak and Speck, 2008). These cells are derived from mesoderm, one of the three primary germ layers of the embryo. This layer along with endoderm and ectoderm is established during a developmental process called gastrulation. In the mouse, cells in the posterior region of the cup-shaped epiblast layer start the process by moving through a transient structure called the primitive streak (PS). As development proceeds the PS extends towards the anterior part of the embryo with mesoderm and endoderm exiting in a temporally and spatially regulated manner (Lawson et al., 1991). Ectoderm is formed by cells from the epiblast that do not traverse the PS.

The posterior PS gives rise to the extraembryonic mesoderm which contributes to the hematopoietic cells and vascular network of the YS, the embryonic contribution to the placenta, the umbilical artery and vein, and the amnion (Kinder etal., 1999; Lawson etal., 1991). The first hematopoietic cells to be made are the primitive erythroid progenitors which appear between embryonic day 7.09.0 (E7.0-9.0). Macrophage progenitors appear at about the same time as primitive erythroid progenitors reaching a peak at E9.5. The definite erythroid progenitors follow at E8.25 and definitive progenitors such as mast colony-forming cell (MastCFC) and bipotential granulocyte/macrophage (GM-CFC) progenitors are detected at E8.5 (Palis et al., 1999). These progenitors enter circulation and begin to colonize the fetal liver by late E9.0 (Johnson and Moore, 1975; Lux et al., 2008). By E9.0 a multilineage repopulating stem cell from the YS can be detected using a neonatal reconstitution assay (Yoder et al., 1997). These cells when injected into the liver of conditioned neonates give multilineage engraftment; however they will not do so in an adult repopulating assay which suggests that they are deficient in their ability to home, expand and/or survive in the bone marrow. It is qualitatively different from the adult repopulating HSC that appears in the YS at around E11.0 (Moore and Metcalf, 1970; Muller et al., 1994). Since other sites in the embryo contain HSCs prior to the YS, it has been assumed that they arrive there by circulation (Medvinsky and Dzierzak, 1996).

The intraembryonic AGM develops from the para-aortic splanchnopleura (P-Sp) which when isolated prior to circulation and cultured as an explant for a few days reveals the presence of a cell that gives low but multilineage repopulation in irradiated immune-deficient Rag2 $\gamma^{-/-}$recipients (Cumano et al., 2001). This study demonstrates that the P-Sp/AGM comprises an intraembryonic site of hematopoiesis. At E9.0 neonatal repopulating cells can be detected in the P-Sp (Yoder et al., 1997). Then prior to HSC appearance in the YS, they can be found in the AGM at E10.5 (de Bruijn et al., 2000; Medvinsky and Dzierzak, 1996; Muller et al., 1994). Taken together with the observation that the AGM is not a site for hematopoietic progenitor differentiation (Godin et al., 1999) the P-Sp/AGM can be considered a site that generates cells with repopulating potential (Dzierzak and Speck, 2008).

The placenta, which was initially identified as a niche for HSCs appears to be yet another site of hematopoietic generation (Alvarez-Silva et al., 2003; Gekas et al., 2005; Ottersbach and Dzierzak, 2005; Rhodes et al., 2008; Zeigler et al., 2006). The placenta along with the vitelline and umbilical arteries, which connect it to the embryo, harbor HSCs at the same time that they appear in the AGM (de Bruijn et al., 2000; Gekas et al., 2005). By using a mouse that lacks circulation it could be shown that the placenta can give rise to erythroid, myeloid and lymphoid lineages, a hallmark of the multipotential HSCs (Rhodes et al., 2008). Further in vivostudies on these placental cells will address their true HSC potential. The mesodermal component of the placenta is comprised of both chorionic and allantoic mesoderm, while that of the vitelline and umbilical arteries is from allantoic mesoderm (Downs, 2002). When isolated from embryos prior to the chorioallantoic fusion necessary to form the placenta, both the chorion and allantois showed hematopoietic potential (Corbel et al., 2007; Zeigler et al., 2006). Together this data point to the placenta as another site of hematopoietic cell generation.

If we consider the PS origins of the different hematopoietic sites we see that the chorion, YS blood islands and allantois are populated by the extraembryonic mesoderm which migrates early from the posterior PS and could contribute to these structures in an overlapping time window (Kinder et al., 1999). The P-Sp/AGM is generated from lateral plate mesoderm which migrates from the PS later during gastrulation and tends to emanate from more anterior positions in the PS than the extraembryonic mesoderm (Kinder et al., 1999). The spatial and temporal generation of mesoderm in the PS may thus play an important role in determining the kinds of hematopoietic cells that develop. The subsequent migration of the mesoderm into different embryonic locations provides addition environmental cues that could influence the timing of hematopoietic cell appearance and the type of hematopoietic cell that develops. For example, the mesoderm that gives rise to the YS blood islands and placenta are potentially exiting the streak at the same time however the environment in the YS versus the allantois or chorion may influence further hematopoietic differentiation (Fig. 1).

To understand the transition of mesoderm to hematopoietic cells, intermediate stages need to be identified and characterized. Many years ago, a cell called the hemangioblast was hypothesized to exist as a precursor to the hematopoietic and endothelial lineages on observation of the close physical proximity of these lineages in the chick YS (Sabin, 1920). That hematopoietic and endothelial cells share markers in common and are both affected by the deletion of certain genes lent further support to this hypothesis (Carmeliet et al., 1996; Ferrara et al., 1996; Fong et al., 1996; Kabrun et al., 1997; Kallianpur et al., 1994; Millauer et al., 1993; Shalaby et al., 1997; Shalaby et al., 1995; Watt et al., 1995; Yamaguchi et al., 1993; Young et al., 1995). The appearance of hematopoietic cell clusters juxtaposed to endothelium in the AGM, the vitelline and umbilical arteries and most recently in the placenta has also suggested a close relationship between 
these lineages (de Bruijn et al., 2000; Jaffredo et al., 2005; Rhodes et al., 2008). These observations have been used to propose the existence of specialized endothelial cells with hematopoietic potential called hemogenic endothelium. The hematopoietic cell clusters of the AGM and underlying endothelium express some common markers (CD31, VE-cadherin, Sca-1, Runx1) (de Bruijn et al., 2002; Garcia-Porrero et al., 1998; Nishikawa et al., 1998a; North et al., 1999). Recently, using an inducible VE-cadherin Cre mouse line crossed to a Rosa26R Cre reporter mouse line it was shown that VE-cadherin+ endothelium is the source of HSCs in the AGM (Zovein et al., 2008). Indeed when Runx 1 is deleted in this population, HSCs do not develop (Chen etal., 2009). In contrast, when Runx1 is deleted in hematopoietic cells in the embryo, using the Vav-Cre mouse, HSC generation occurs. This indicates that Runx1 activity essential to hematopoietic development is absolutely required in an endothelial cell (Chen et al., 2009).

An area termed the subaortic patch (SAP) that lies under the dorsal aorta has also been proposed as a source of the HSCs (Bertrand et al., 2005). To address the question of a subaortic origin of the HSCs, SM $22 \alpha$ Cre and myocardin Cre mouse lines were used where the former enabled the marking of an early and late mesodermal population while the latter led to the labelling only of the late mesodermal population. Only the early labelled mesodermal population, which could give rise to aortic endothelium, contributed cells to the adult bone marrow (Zovein et al., 2008). For subaortic patches to contribute to AGM HSCs, given the findings above, they would have to exist in the early labelled mesodermal population and give rise to HSCs that upregulate VEcadherin as they emerge through the endothelium of the aorta (Chen et al., 2009; Zovein et al., 2008).

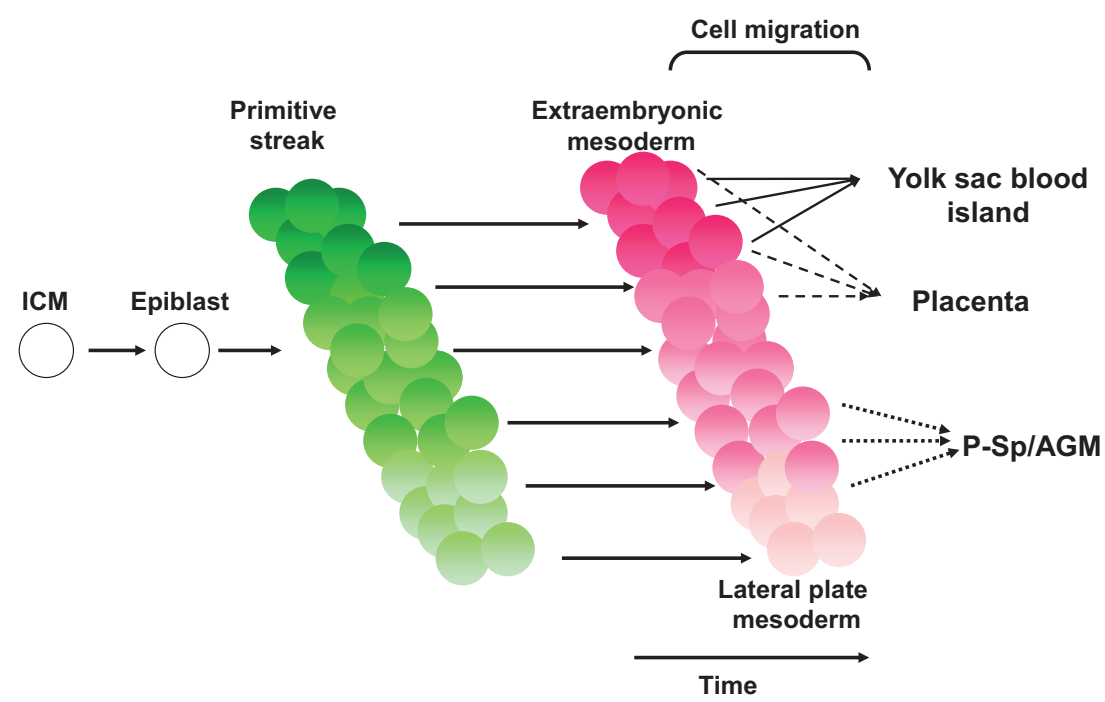

Fig. 1. The generation of embryonic hematopoietic sites from mesoderm. The yolk sac blood islands, placenta and P-Sp/AGM are derived from mesoderm that develops from the PS. The first mesoderm is extraembryonic and migrates away from the posterior primitive streak to populate the chorion, YS, allantois and amnion. The mesoderm that contributes to the YS and placenta migrate in an overlapping time window las indicated by overlapping arrows). The P-Sp/AGM is derived from lateral plate mesoderm that migrates later in time from the PS. How these mesoderm populations differ from each other is not know and may be important to the hematopoietic programs that develop from the different hematopoietic sites.
The strong genetic evidence described here for the existence of hemogenic endothelium is complemented by studies using the ESC differentiation system that support the existence of the hemangioblast and hemogenic endothelium (see later). The identification of these developmental intermediates has enabled researchers to address the mechanism of hematopoietic commitment.

\section{ESC differentiation to hematopoietic lineages}

ESCs self-renew or differentiate based on the culture conditions they are placed in. They can be maintained in their pluripotent state when grown on a layer of feeder cells in the presence of leukemia inhibitory factor (LIF) and serum (Chambers and Smith, 2004; Smith et al., 1988; Williams et al., 1988). Differentiation protocols have typically involved the removal of ESCs from this environment and the subsequent culture of these cells in suspension as aggregates known as embryoid bodies (EBs) or as adherent monolayers on either extracellular matrices or stromal cell lines. All of these culturing approaches, sometimes in combination have been used in protocols to generate hematopoietic cells. The popularity of the EB method can be attributed to the observation that development proceeds well when cells are in a ee-dimensional structure, presumably as it offers an environent layers on extracellular matrices such as collagen IV offers better access to the cells, not only to expose them to more consistent culture conditions but also to visualize them as they develop. Supportive stroma derived from adult bone marrow, fetal liver and AGM are used in the hematopoietic field to promote the differentiation, proliferation and maintenance of ex vivo hematopoietic cells (Moore et al., 1997; Nakano et al., 1994; Oostendorp et al., 2002; Weisel et al., 2006; Xu et al., 1998). Some of these stromal cell lines have been successfully used to promote ES cell differentiation to hematopoietic cells.

Protocols that allow for the production of murine and human primitive and definite hematopoietic cell lineages have been reviewed recently and will not be discussed in detail here (Murry and Keller, 2008; Olsen et al., 2006; Orlovskaya et al., 2008; Tian and Kaufman, 2008). ESCs are generally differentiated as EBs or on stroma in the presence of cytokines that promote specific lineages. For example, ESCs will develop into T lymphoid cells on coculture with OP9 cells modified to express the Notch ligand Delta-like 1 and in the presence of IL7 and Flt3 ligand (Schmitt et al., 2004). The ability to generate definitive erythroid, myeloid and lymphoid lineages from ESC cultures suggests that HSCs are being induced; however protocols describing HSC differentiations have not gained wide usage (Burt et al., 2004; Tian et al., 2006; Wang et al., 2005a). Recently, stroma derived from mouse AGMs was able to support the development of hematopoietic cells from human ESCs that could repopulate the immune compromised NOD/LtSzScid/L2 $\gamma^{\prime-}$ mouse (Ledran et al., 2008). The cells showed serial repopulation activity; however they 
display an embryonic and fetal globin profile in culture. Further studies are needed to study the multilineage potential of these cells. Common to this and other studies on ESC-derived repopulating cells is the direct injection of cells into the femur when performing mouse transplantations. This highlights the concern that differentiation protocols still have to provide the appropriate maturation of cells for successful engraftment and bypass problems such as cell aggregation based emboli formation. While it is helpful to work with stroma that mimic the embryonic HSC niche, efforts to identify the stromal components that support the maintenance and differentiation of hematopoietic cells will aid in developing defined differentiation protocols that do not require cell coculture steps. The study by Ledran and colleagues identified TGF $\beta 1$ and TGF $\beta 3$ as factors involved in positively regulating the hematopoietic differentiation from hESCs. Thus far multilineage reconstitution in the mouse has been achieved with ESC-derived hematopoietic cells generated by overexpression of the Hox family member, HoxB4, and caudal-related transcription factor Cdx4 (Wang et al., 2005b). In brief, there are protocols available to generate different hematopoietic lineages. However defined, serum-free and coculture-free protocols to reproducibly generate robust levels of adult repopulating HSCs from genetically unmanipulated ESCs are still lacking.

\section{Tools of ESC differentiation}

As a developmental system the ESC differentiation model has some clear advantages. The high proliferative potential of ESCs allows for experiments on a scale that is not feasible with embryonic tissues. In order to establish the role of a particular gene or signalling pathway, the investigator has various ways to adjust gene expression or modulate the activity of a signalling pathway. Of particular help are ESC lines that allow for the inducible expression of a gene of interest by the addition of doxycycline, a tetracycline analog (Kyba etal., 2002). This is a powerful resource as gene overexpression can be limited to the time window of interest. Loss of function experiments are performed using standard knockout cell lines, siRNA transfection for knock down of RNA transcripts and inducible siRNA cell lines to control the timing of RNA knockdown (Lohmann and Bieker, 2008; Wang et al., 2007b). Signalling pathways are stimulated through the addition of growth factors or agonists and blocked by addition of natural-occurring inhibitors, chimeric receptors, or small inhibitory compounds. When these tools are used together they can establish how factors mediate their effects and whether they act through the induction of other signalling pathways.

Flow cytometry has been used both in the hematopoietic and ESC differentiation systems to determine cell diversity in cultures, track differentiation progress, and isolate and identify distinct cell populations. The ability to assess early stages of ESC differentiation is of particular use to the understanding of lineage commitment decisions. When tracking mesoderm development one can use the expression of the VEGF receptor, Flk-1, and/or the PDGF receptor alpha, PDGFR $\alpha$. Nascent mesoderm expresses both markers but on further commitment lateral plate and extraembryonic mesoderm down-regulate PDGFR $\alpha$ and continue to express Flk-1, while paraxial mesoderm down-regulate Flk-1 and maintain PDGFR $\alpha$ expression (Ema et al., 2006; Sakurai et al., 2006; Takakura et al., 1997). Lineage tracing experiments confirm that hematopoietic, cardiac, somatic and smooth muscle all transition through cells that expressed Flk-1 at some point during development (Ema et al., 2006; Lugus et al., 2008). To use a cell-type specific marker that is not on the cell surface one can use a reporter ESC line where a fluorescent protein (e.g. eGFP) or a cell-surface molecule from a different species (e.g. truncated human CD4) is expressed from the marker's promoter (Chung et al., 2002; Fehling et al., 2003; Gadue et al., 2006; Ng et al., 2005; Tada et al., 2005). The development of PS-like cells in ESC differentiation cultures has been tracked using eGFP driven from the promoters of PS markers brachyuryand mixl. 1 (Fehling et al., 2003; $\mathrm{Ng}$ et al., 2005). Both groups observed a GFP+ population by day 2.5 of EB differentiation that increased and peaked by day 4 where they comprise $85 \%$ of cells. The levels of GFP then fall on further EB differentiation which is consistent with cells transiting out of the PS stage as observed in the mouse embryo. The PS streak population can be further separated into anterior and posterior PS based on the expression of the anterior PS gene, Foxa2. Human CD4 cDNA was targeted to the foxa2locus in the GFP-Bry ESC line which allows for the identification of anterior PS ${\text { (GFP-Bry }{ }^{+} \text {CD4-Foxa2 }}^{\text {hi }}$ ) and posterior PS (GFP-Bry+CD4-Foxa2 ${ }^{\mathrm{lo} / \text { - }}$ ) populations in EB cultures (Gadue et al., 2006).

Recently efforts have moved towards using defined and optimized culture conditions for maintaining and differentiating ESCs. The use of serum-free media and growth factors and/or small molecules removes the need to work with serum, a component that is prone to variation and can pose a challenge for labs when they attempt to replicate other groups' protocols. The self-renewal of ESCs can be sustained in the absence of feeders and serum, by the addition of BMP4 and LIF to serum-free media (Qi et al., 2004; Ying et al., 2003). And more recently a combination of three inhibitors termed $3 \mathrm{i}$ that inhibit FGF signalling and glycogen synthase kinase 3 (GSK3) activity were found to support ESC maintenance (Ying et al., 2008). FGF4 is produced by ESCs and is needed for cells to respond to differentiation signals while GSK3 activity in ESCs appears to negatively influence their metabolic state (Kunath et al., 2007; Ying et al., 2008). Serum-free differentiation protocols for specific tissue types are being developed by incorporating what is known from studies in various developmental systems. This developmental biology approach has been successfully applied to the differentiation of the YS hematopoietic program from ESCs (see later in this review). By providing the appropriate signals at levels and with the timing reflective of the embryonic environment through combinations of growth factors/ small molecules, and extracellular matrices one can theoretically promote the hematopoietic programs of the YS, P-Sp/AGM, placenta and vitelline/umbilical arteries. This approach is relevant to the efforts to generate HSCs from ESC cultures.

\section{Characterizing the hemangioblast and hemogenic en- dothelium}

The ESC differentiation system provided the first functional evidence for the existence of the bipotential hemangioblast. $A$ progenitor with both endothelial and hematopoietic potential arises when ESCs are differentiated as EBs or as a monolayer on collagen IV (Choi et al., 1998; Nishikawa et al., 1998b). This cell appears earlier than hematopoietic progenitors which are typically detected after day 5 of ESC differentiation. A methycellulose- 
based colony assay supplemented with VEGF, IL6 and the supernatant of an endothelial cell line called D4T, allows for the culture and quantification of hemangioblasts, which form a morphologically distinct colony called the blast colony (Choi et al., 1998; Kennedy et al., 1997). Clonal analysis demonstrated that the colonies were derived from a single cell termed the BlastColony Forming Cell (BL-CFC) and represents the in vitro hemangioblast. Recently, a serum-free blast colony assay was developed using ten cytokines (KL, IL3, BMP4, IL11, EPO, VEGF, LIF, IL6, bFGF, TGF $\beta 1$ ) which replaced the need for serum and D4T supernatant (Cheng et al., 2008). The ability to capture this developmental stage provides a means to characterize it and determine the factors needed for its generation and further differentiation.

BL-CFCs/hemangioblasts are found in the Flk-1+ mesoderm population that develops in EBs (Faloon etal., 2000; Fehling etal., 2003; Nishikawa et al., 1998b). This is consistent with the findings that the cells of the YS blood island go through a Flk-1+ cell stage during development (Ema et al., 2006; Lugus et al., 2008). The BMP signalling pathway has been implicated in the generation of BL-CFCs and the regulation of key hematopoietic transcription factors. Its downstream effector Smad1 is more highly expressed in the BL-CFC-enriched population (Bry-GFP+Flk-1+) compared to PS (Bry-GFP+Flk-1') and non-PS (Bry-GFP-Flk-1') EB cells (Zafonte et al., 2007). Overexpression of Smad1 in the presence of serum during PS induction and patterning (EB day 2-2.25) led to a statistically significant upregulation of the hematopoietic transcription factors GATA2, Runx1 and SCL by day 2.25, a subsequent increase in Flk-1 expression by day 3 and a 5 -fold increase in BL-CFCs by day 3.75 compared to uninduced cells. GATA2 is expressed in a BL-CFC enriched population (Flk$1+\mathrm{Scl}+$ cells from day $2.75 \mathrm{EBs}$ ) and is downregulated in the progeny of the BL-CFCs, the blast colonies. When overexpressed in serum-free cultures during PS induction and patterning, GATA2 can increase the Flk-1 + population and lead to increased primitive erythroid progenitors (Lugus et al., 2007). The basic helix-loophelix transcription factor, SCL is essential for the commitment of BL-CFCs to the hematopoietic fate. In its absence, blast colonies do not develop in the blast assay; this is not because BL-CFCs are absent but rather that they can not give rise to hematopoietic progeny and thus do not form recognizable blast colonies (D'Souza et al., 2005). Overexpression of SCL from EB day 2-4 leads to an increase in the Flk-1+ population and from EB day 3-4 gives rise to higher levels of the hematopoietic markers CD41 and CD45 at EB day 6 (Ismailoglu et al., 2008). The Ets family member ER71, is also expressed in BL-CFC enriched populations and on overexpression in serum-free conditions from EB day 2-4 will lead to induction of a Flk-1+ cell population and from EB day 3 will lead to the generation of hematopoietic and endothelial cells(Lee etal., 2008; Lugus et al., 2007).

GATA2, SCL and ER71 appear to have overlapping effects when overexpressed as EBs during PS induction and patterning. Interestingly, GATA2, SCL, and the Ets family member, Fli1, and their enhancers Gata2-3, SCl +19 and Flit +12 comprise a hemangioblast and hematopoietic stem cell gene regulatory network (GRN) kernel (Liu et al., 2008; Pimanda et al., 2007b). GRN kernels are conserved subcircuits comprised of regulatory genes and their target enhancer elements, and can serve key instructive functions during development (Davidson and Erwin,
2006; Hinman et al., 2003). The expression levels of gata2, scl and flit are higher in the BL-CFC-enriched population (BryGFP ${ }^{+} F \mathrm{Ik}-1^{+}$) compared to PS (Bry-GFP+Flk-1') and non-PS (BryGFP-Flk-1') EB cells (Pimanda etal., 2007b). Chromatin immunoprecipitation experiments show that the three transcription factors bind to their respective enhancers in day 3 EBs indicating that these sites are bound at a time BL-CFCs are present. The lossof-function phenotype for ER71 shows that it is essential for both hematopoietic and endothelial cell development in the YS; however a similar result was not found for Fli1 (Hart et al., 2000; Lee et al., 2008; Spyropoulos et al., 2000). This suggests that ER71 is a critical Ets family member and may be part of the hemangioblast GRN kernel. This is in contrast to findings in zebrafish and Xenopus where Fli1 appears to be a master regulator for hematopoietic and endothelial development (Liu et al., 2008). Analysis of the role of Fli1 in BL-CFC development would expand our understanding of its involvement in the hemangioblast GRN kernel.

Other transcription factors can be integrated into the hemangioblast GRN. Runx 1 which is regulated by BMP signalling is essential for definitive hematopoiesis (Lacaud et al., 2002; Pimanda etal., 2007a). It starts to be expressed in the blast colony after 24 hours of colony growth; over the next 24 hours of blast colony development there is a great increase in the appearance of definitive progenitors (Cheng et al., 2008). The homeobox transcription factor Hex is expressed in BL-CFCs and acts to negatively regulate the levels of this progenitor (Kubo et al., 2005). In addition, it appears dispensable for primitive erythroid formation but required for differentiation of definitive hematopoietic and endothelial cells (Guo et al., 2003; Kubo et al., 2005). The $C d x$ genes, $C d x 1$ and $C d x 4$, are critical to the development of blood in the zebrafish system through their regulation of Hox genes that promote posterior/hematopoietic fate (Davidson et al., 2003; Davidson and Zon, 2006). The mouse Cdx genes, $C d x 1$ and $C d x 4$, show redundant functions in promoting posterior patterning through the regulation of posterior Hoxgenes (Lohnes, 2003; Subramanian et al., 1995; van den Akker et al., 2002; van Nes et al., 2006). They are expressed during EB differentiation in overlapping time windows which include the period of BL-CFC generation (Lengerke et al., 2008; McKinney-Freeman et al., 2008). When $C d x 4$ is overexpressed from day 2-4 of serum differentiation and during the blast colony assay it leads to an increase in BL-CFCs (Wang et al., 2005b). While its effect on BLCFC numbers was not reported, overexpression of $C d x 1$ during the same time window leads to an increase in hematopoietic progenitors (McKinney-Freeman et al., 2008). $C d \times 1$ or $C d \times 4$ homozygous null mice do not appear to have altered hematopoietic development, however, ESCs deficient for either of these genes show reduced hematopoietic potential that can be further abrogated when the remaining $C d x$ genes including family member $C d \times 2$ are reduced (Wang et al., 2008). These results point to the importance of the $C d x$-hoxpathway in regulating commitment and proliferation of the hematopoietic lineage.

Supplying additional levels of regulation in BL-CFC fate determination are factors that may act by modulating signalling pathways. Endoglin (CD105), an accessory receptor for TGF $\beta$ superfamily members, is expressed on BL-CFCs and when absent leads to a significant reduction in blast colony numbers (Perlingeiro, 2007). It can complex with TGF $\beta$ superfamily ligands (e.g. ActivinA, TGF $\beta 1$, BMP2) and their receptors (e.g. type 1 receptors ALK3 
and ALK6, and type II receptors TBRII, ActRIIA and ActRIIB) (Bernabeu et al., 2007). This association may regulate the activity of BMPs, Activin/Nodal and TGF $\beta$ in the BL-CFC formation process and warrants further dissection. The lysocardiolipin acyltransferase (Lycat) catalyzes the addition of palmitate groups to proteins such as cardiolipin (Cao et al., 2004). It is expressed in the Flk-1+ BL-CFC-containing populations of day $4 \mathrm{EBs}$ and on overexpression in a transgenic cell line leads to increased BLCFCs and hematopoietic progenitors (Wang et al., 2007a). Acyltransferases have been shown to affect signalling in the Hedgehog and Wnt pathways by acting upon the ligands (Buglino and Resh, 2008; Chamoun et al., 2001; Kadowaki et al., 1996; Micchelli et al., 2002). It would be interesting to determine what substrates, particularly factors in signalling pathways Lycat might act upon to impact BL-CFC commitment and development.

When the blast colony culture conditions were used on dispersed E7.5 mouse embryos, hemangioblasts could be identified. They displayed many of the features of their in vitro counterparts; they possessed hematopoietic and endothelial potential and were a subpopulation of Flk-1+ mesoderm (Bry-GFP+Flk-1+) (Huber et al., 2004). They were most abundantly found in the posterior PS indicating that commitment to the hemangioblast fate occurred in the PS prior to migration of mesoderm into the YS. Interestingly, primitive erythroid progenitors are observed near the PS (the distal YS) at E7.25 (Ferkowicz et al., 2003). This finding fits with a model of YS blood island formation where the hemangioblast divides into endothelial and hematopoietic precursors, in particular primitive erythroid precursors, soon after it migrates from the PS into the YS. Besides hemangioblasts, angioblasts also arise from the posterior PS and contribute to the endothelial cells of the YS (Furuta et al., 2006). Primitive erythroid precursors then migrate to the proximal YS and exist extravascularly as a band of cells until they are partially ensheathed by endothelial cells to form what has long been considered a YS blood island (Ferkowicz and Yoder, 2005). Rather than being surrounded in endothelium the blood cells are subdivided into endothelial channels that ultimately stream into the primary vascular plexus of the YS. This model may offer an explanation for why lineage tracing has thus far questioned the contribution of hemangioblasts to the YS blood island (Kinder etal., 1999; Ueno and Weissman, 2006). If the existence of a hemangioblast is inferred from the presence of labelled hematopoietic and endothelial cells in the same section of a "blood island" then the presence of this cell may be underestimated. This is because the hematopoietic and endothelial lineages from the hemangioblasts appear to separate early and with the intermingling of cells in the YS the hematopoietic and endothelial progeny of a hemangioblast may not in fact be in close proximity to each other by the time blood islands are inspected.

BL-CFCs have been detected in hESC differentiation cultures. Depending on the culture conditions used they can appear as early as day 3-4 or later from day 5-12 of EB culture (Davis et al., 2008; Kennedy et al., 2007; Lu et al., 2007; Wang et al., 2004; Zambidis et al., 2005). hBL-CFCs express the Flk-1 homologue, KDR as seen in the mouse system (Kennedy etal., 2007; Wang etal., 2004) and are found enriched in the MIXL1-GFP+PDGR $\alpha^{+}$cells that represent an early mesoderm population (Davis et al., 2008). They have also been found to express the angiotensin-converting enzyme (ACE, CD143) which has been identified as a marker of human HSCs (Jokubaitis et al., 2008). hBL-CFCs exist as a transient population prior to the appearance of hematopoietic progenitors and they can give rise to both hematopoietic and endothelial progeny. Serum-free protocols used to generate EBs have used either a single culture condition (BMP4, VEGF, SCF) or a multi-step approach with BMP4 present since the initiation of EB culture and later addition of VEGF(Davis et al., 2008; Kennedy et al., 2007; Lu et al., 2007). A serum-free human blast colony protocol was developed and includes BMP4, VEGF, FGF2, heparan sulphate and TPO (Zambidis et al., 2008). Further discussions of human hemangioblasts are covered in the review by Zambidis et al. (2010).

Recently, two papers demonstrated the existence of hemogenic endothelium using the mouse ESC system (Eilken et al., 2009; Lancrin et al., 2009). When the hemangioblast-containing Flk-1+ population is plated in liquid blast conditions and cultured for two days a population of endothelial cells, marked by the endothelial marker Tie2 and c-kit and lacking the hematopoietic marker CD41 (Tie2 ${ }^{\text {hi }}$-kit ${ }^{+}$CD41-), arises (Lancrin et al., 2009). This population contains clonogenic endothelial cells that can give rise to hematopoietic progeny. This hemogenic population can also be identified from mouse neural plate stage embryos and E10.5 AGMs, indicating that this intermediate exists in vivo during two periods when hematopoietic cells are generated. By using time-lapse microscopy and morphological and molecular markers, the emergence of hematopoietic cells was observed from endothelial cells that arise in cultures of Flk-1+E-cadherin- mesoderm plated on OP9 stroma (Eilken et al., 2009). Hemogenic endothelial cells were observed to express VE-cadherin, form tight junctions and take up acetylated low density lipoprotein (Ac-LDL) and reside in an endothelial sheet. They then divide into cells that upregulate the hematopoietic markers CD41 and CD45, and migrate out of the endothelial sheet. The first division of the hemogenic endothelial cells gives rise to two daughter hematopoietic cells. Thus the hemangioblast is a cell with hematopoietic and endothelial potential and hemogenic endothelium is a cell with endothelial identity that gives rise to hematopoietic progeny. The findings from these papers allow for the placement of the hemogenic endothelium stage after the hemangioblast stage in a single developmental process, reconciling what appeared to be two alternate theories of how hematopoietic cells arise.

The function of the hematopoietic transcription factors, SCL and Runx1 were studied with relation to the hemogenic endothelium developmental stage. SCL-/- ES cells do not generate the Tie $2^{\text {hi }} \mathrm{C}$ $\mathrm{kit}^{+} \mathrm{CD} 41^{-}$population indicating that $\mathrm{SCL}$ is critical for the development of the hemogenic endothelial stage (Lancrin et al., 2009). In contrast, from studies using a Runx $1^{-1-}$ ES cell line that can be induced to express Runx1 (iRunx1), the Tie $2{ }^{\text {hi }} \mathrm{c}-\mathrm{kit}^{+} \mathrm{CD} 41$. hemogenic endothelium was shown to arise independently of Runx1 while the formation of definite hematopoietic cells from this population requires Runx1. This is consistent with the findings from the mouse embryo studies (Chen et al., 2009). With the ability to access the hemogenic endothelium, studies can now focus on the cell intrinsic and extrinsic signals that lead to hematopoietic commitment at the level of this developmental stage.

\section{Dissecting the signalling requirements for the YS he- matopoietic program}

The process of hematopoietic differentiation can be expressed 
as a progression through developmental stages (Fig. 2). ESCs differentiate into epiblast-like cells that are induced to become PS cells (step 1). These cells are patterned to a posterior fate and develop into a Flk-1-expressing extraembryonic/lateral plate mesoderm cell that has hematopoietic potential, known as a hemangioblast (step 2). As there are other fates for Flk-1 mesoderm this commitment to hematopoietic mesoderm/hemangioblast is a significant step. The hemangioblast gives rise to hematopoietic progenitors (primitive or definitive) and vascular cells. The roles of the BMP, Wnt, Activin/Nodal, Notch, FGF and VEGF signalling pathways have been assessed in this differentiation process (Cheng et al., 2008; Faloon et al., 2000; Lengerke et al., 2008; Nostro etal., 2008; Park etal., 2004; Pearson etal., 2008). This has identified distinct signalling requirements for the different transitions during hematopoietic development. When BMP4 is added to ES cultures under serum-free conditions it can induce the formation of the PS and Flk-1+ mesoderm but compared to cultures treated with serum, it promotes lower levels of hematopoietic commitment and differentiation as determined by hematopoietic colony assays and hematopoietic marker analysis (Johansson and Wiles, 1995; Ng et al., 2005; Nostro et al., 2008; Park et al., 2005; Pearson et al., 2008). This indicates that the addition of BMP4 alone is not enough to robustly promote the hematopoietic program.

ES cells treated with BMP4 generate a posterior PS-like population (GFP-Bry+CD4-Foxa2 ${ }^{\text {lo) }}$ (Nostro et al., 2008). The addition of inhibitors of the Wnt and Activin/Nodal pathways however prevent the formation of this population, indicating that BMP4 induces the PS indirectly through the action of Wnt and Activin/Nodal (Fig. 2, Step 1). In turn, Wnt and Activin have been shown to individually be capable of inducing PS populations; however, they require the action of the other in order to do this

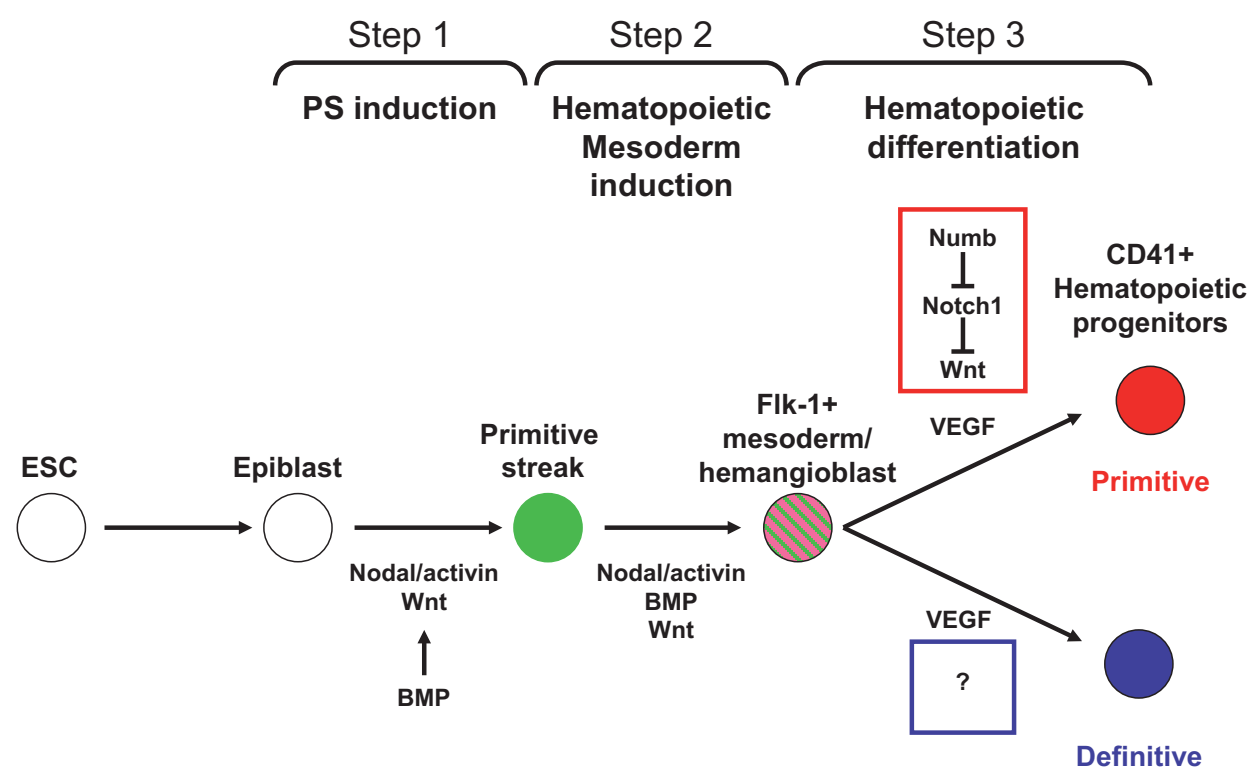

Fig. 2. Growth factor requirements in hematopoietic differentiation in ESC Cultures. ESCS differentiate into epiblast that is induced to form the PS. Posterior patterning of the PS leads to Flk$1+$ mesoderm/hemangioblast induction. Hematopoietic progenitors differentiate from the Flk-1+ mesoderm/hemangioblast in response to VEGF. The primitive hematopoietic lineage is dependent on Wnt signaling while the pathways responsible for definitive lineages are not known. Modified from Nostro et al. (2008).
(Gadue et al., 2006). The addition of BMP4 to Wnt and Activin will shift the PS population induced from an anterior PS (GFPBry ${ }^{+}$CD4-Foxa2 ${ }^{\text {mid-high }}$ ) to posterior PS fate (GFP-Bry ${ }^{+}$CD4Foxa2 ${ }^{\text {lo }}$ ) (Nostro et al., 2008). This shows that BMP signalling can pattern the PS which is a finding consistent with the patterning roles of BMP4 observed in other developmental systems (Kishimoto et al., 1997; Maeno et al., 1994; Mullins et al., 1996; Re'em-Kalma et al., 1995).

The next transition of the PS to Flk-1+ hematopoietic mesoderm/hemangioblasts is when BMP, Activin/Nodal, and Wnt signalling serve nonredundant functions (Fig. 2, step 2) (Nostro et al., 2008). As PS cells are not fully committed to a particular anteriorposterior fate this transition is sensitive to factors that regulate PS patterning (Gadue etal., 2006; Nostro et al., 2008). The patterning role of BMP signalling is important at this stage. It has recently been linked to the axis patterning $C d x$-hox pathway through the action of Wnt (Lengerke et al., 2008). In the absence of Wnt signalling, BMP4 in serum-free media can not promote hematopoietic induction from a serum-induced day 2.25 PS-containing EB population. The overexpression of $C d \times 1$ and $C d \times 4$ can substitute for BMP4 in the same time window to induce hematopoietic development. BMP4 appears to activate the expression of the $C d x$ genes through the activity of Wnt3a. It will be important to establish how the $C d x$-hox pathway promote hematopoietic fate, particularly how it might influence the expression of hematopoietic transcription factors such as SCL.

A role for Activin/Nodal in combination with bFGF in promoting Flk-1 + hematopoietic mesoderm/hemangioblasts was also shown by Pearson at al. The addition of Activin and bFGF to unsorted cultures of day 2.25 BMP4-treated ESCs resulted in a strong induction of BL-CFC numbers compared to just addition of BMP4 alone (Pearson et al., 2008). Activin and bFGF, in the presence of BMP4 led to an induction of Runx 1 , Hex, Scl, Fli1, and Lmo2within the first 6 hours of stimulation. bFGF has previously been shown to stimulate the proliferation of Flk-1+ mesoderm rather than promote its formation so it is possible that the induction of hematopoietic transcription factors in this study may be stimulated by activin (Faloon etal., 2000; Park et al., 2004). Experiments without bFGF and with inhibitors to the FGF pathway would clarify the contribution of this growth factor.

The transition of Flk-1+ mesoderm/ hemangioblast to hematopoietic progenitors requires VEGF as in its absence hematopoietic progenitors do not arise even when conditions to generate robust BL-CFCs are used (Fig. 2, Step 3) (Nostro et al., 2008; Park et al., 2005; Pearson et al., 2008). VEGF appears to act by sustaining the expression of the hematopoietic transcription factors Scl, Fli1 and Lmo2that have been initiated during the generation of the Flk-1+ mesoderm/ hemangioblast (Pearson et al., 2008). This effect can not be replicated by the 
addition of BMP4, Activin or Wnt (Nostro et al., 2008). However, when the Wnt pathway is inhibited in the presence of VEGF, the primitive erythroid lineage is suppressed indicating that Wnt signalling is required for the generation of these cells from Flk-1+ mesoderm/hemangioblasts (Fig. 2, Step 3, red box) (Nostro etal., 2008). Wnt signalling functions early in this process as addition of the Wnt inhibitor DKK up to 6 hours into culture will reduce the number of primitive erythroid progenitors whereas addition at 12 hrs essentially does not have an effect. In addition Wnt signalling is modulated by the interaction between Notch1 and its negative regulator, Numb (Cheng et al., 2008). The activation of Notch signalling in Flk-1 + mesoderm leads to an increase in the expression of Wnt inhibitors and a consequent reduction in Wnt signalling thus abrogating primitive erythroid formation. In contrast overexpression of Numb in Flk-1+ cells leads to reduced Wnt inhibitor expression, enhanced levels of Wnt signalling and hence increased primitive erythroid potential. The definitive hematopoietic potential from the Flk-1+ mesoderm/hemangioblast, at least as determined by total definitive colony counts in hematopoietic colony assays, appears unaffected by changes in Wnt and Notch1 signalling suggesting that other pathways are critical to the appearance of this program (Fig. 2, Step 3 blue box). However, this does not rule out effects that these pathways may have on the types of definitive progenitors that arise.

Efforts to establish the growth factor requirements for developmental transitions can lead to optimized serum-free directed differentiation protocols. This is borne out by the observation that serum-free conditions to generate hematopoietic progenitors and culture blast colonies performed better than the initial serumcontaining protocols (Cheng et al., 2008; Pearson et al., 2008). In the hESC system, BMP4 and VEGF are common to serum-free protocols to generate hematopoietic progeny (Davis et al., 2008; Kennedy et al., 2007; Lu et al., 2007; Pick et al., 2007; Tian et al., 2004; Zambidis et al., 2008). Other growth factors that have been included in protocols are SCF, FGF1, FGF2, TPO and Flt3L (Davis etal., 2008; Kennedy et al., 2007; Lu et al., 2007; Zambidis et al., 2008). As in the mouse system, BMP4, Activin/Nodal and Wnt can individually induce the formation of EB populations that express PS markers (Davis et al., 2008; Sumi et al., 2008). However the assessment of the growth factor requirements for each step in human hematopoietic differentiation awaits analysis of the kind of detail performed in the mouse system.

\section{Concluding remarks}

Our ability to differentiate hematopoietic cells from mouse ESCs has advanced significantly over the last 20 years. Where initially hematopoietic cells were induced in a poorly defined serum-containing medium, differentiation can now be directed towards the YS hematopoietic program in a robust fashion using specific factors added in multi-step protocols derived from our understanding of development in vivo. This approach has been successfully applied to the differentiation of other tissue types such as pancreatic endocrine cells (D'Amour et al., 2006) and certainly is the future for generating cell lineages for cell replacement therapy. Currently, the goal of deriving adult repopulating HSCs requires the ability to develop protocols that promote the AGM or possibly placental program over the YS program. This can benefit from a better understanding of the developmental steps that lead to the generation of the HSC and includes determining the factors that promote proper HSC maturation so that they will effectively home and repopulate in an adult reconstitution assay. The development of an ex vivo AGM culture system and the characterization of supportive stroma are directions that can yield information to apply to differentiation protocols (Ledran et al., 2008; Taoudi et al., 2008).

The ESC differentiation system will continue to yield new insights into hematopoietic development. It can help reveal the structure and behaviour of the transcriptional network that determines hematopoietic commitment and differentiation. The high proliferative capacity of ESCs make them ideal for global analyses such as transcriptome profiling and genome-wide mapping of chromatin marks as well as transcription factor binding sites. These approaches have been applied to undifferentiated ESCs and have greatly advanced our knowledge of the molecular regulation of pluripotency (Bibikova et al., 2008; Jaenisch and Young, 2008; Stanton and Bakre, 2007). For these approaches to be fruitful the cell populations for study should be as homogeneous as possible. To this end appropriate reporter ESC lines and cell surface markers enable the isolation of developmentally distinct cell populations from ESC cultures. A comparison of the transcriptome of a hemangioblast-containing population (Flk$1+\mathrm{Scl}+$ cells from day $2.75 \mathrm{EBs}$ ) with that of its progeny (blast colonies) is one example where early stages of the hematopoietic commitment process have been analyzed in a global manner (Lugus et al., 2007). By using high-throughput technologies to establish the transcriptional network and epigenetic regulation during hematopoietic differentiation, one may integrate the knowledge of the roles of key players into a more comprehensive molecular understanding of what governs hematopoietic lineage commitment.

\section{Acknowledgements}

I thank Xin Cheng, Paul Gadue, Stefan Irion and Cristina Nostro for critical reading of the manuscript and helpful suggestions. Tara Huber is supported by the Agency for Science, Technology and Research (A*STAR).

\section{References}

ALVAREZ-SILVA, M., BELO-DIABANGOUAYA, P., SALAUN, J. and DIETERLENLIEVRE, F. (2003). Mouse placenta is a major hematopoietic organ. Development 130: 5437-5444.

BERNABEU, C., CONLEY, B.A. and VARY, C.P. (2007). Novel biochemical pathways of endoglin in vascular cell physiology. $J$ Cell Biochem 102: 13751388.

BERTRAND, J.Y., GIROUX, S., GOLUB, R., KLAINE, M., JALIL, A., BOUCONTET, L., GODIN, I. and CUMANO, A. (2005). Characterization of purified intraembryonic hematopoietic stem cells as a tool to define their site of origin. Proc Nat/ Acad SCI USA 102: 134-139.

BIBIKOVA, M., LAURENT, L.C., REN, B., LORING, J.F. and FAN, J.B. (2008) Unraveling epigenetic regulation in embryonic stem cells. Cel/ Stem Cel/2: 123 134.

BUGLINO, J.A. and RESH, M.D. (2008). Hhat is a palmitoylacyltransferase with specificity for N-palmitoylation of Sonic Hedgehog. J Biol Chem 283: 22076 22088

BURT, R.K., VERDA, L., KIM, D.A., OYAMA, Y., LUO, K. and LINK, C. (2004). Embryonic stem cells as an alternate marrow donor source: engraftment without graft-versus-host disease. J Exp Med 199: 895-904.

CAO, J., LIU, Y., LOCKWOOD, J., BURN, P. and SHI, Y. (2004). A novel cardiolipinremodeling pathway revealed by a gene encoding an endoplasmic reticulumassociated acyl-CoA:Iysocardiolipin acyltransferase (ALCAT1) in mouse. J Biol 
Chem 279: 31727-31734.

CARMEliet, P., FERREIRA, V., BREIER, G., POLLEFEYT, S., KIECKENS, L., GERTSENSTEIN, M., FAHRIG, M., VANDENHOECK, A., HARPAL, K. and EBEFHARDT, C. (1996). Abnormal blood vessel development and lethality in embryos lacking a single VEGF allele. Nature 380: 435-439.

CHAMBERS, I. and SMITH, A. (2004). Self-renewal of teratocarcinoma and embryonic stem cells. Oncogene 23: 7150-7160.

CHAMOUN, Z., MANN, R.K., NELLEN, D., VON KESSLER, D.P., BELLOTTO, M., BEACHY, P.A. and BASLER, K. (2001). Skinny hedgehog, an acyltransferase required for palmitoylation and activity of the hedgehog signal. Science 293: 2080-2084.

CHEN, M.J., YOKOMIZO, T., ZEIGLER, B.M., DZIERZAK, E. and SPECK, N.A. (2009). Runx1 is required for the endothelial to haematopoietic cell transition but not thereafter. Nature 457: 887-891.

CHENG, X., HUBER, T.L., CHEN, V.C., GADUE, P. and KELLER, G.M. (2008). Numb mediates the interaction between Wnt and Notch to modulate primitive erythropoietic specification from the hemangioblast. Development 135: 34473458.

CHOI, K., KENNEDY, M., KAZAROV, A., PAPADIMITRIOU, J.C. and KELLER, G. (1998). A common precursor for hematopoietic and endothelial cells. Development 125: 725-732.

CHUNG, Y.S., ZHANG, W.J., ARENTSON, E., KINGSLEY, P.D., PALIS, J. and $\mathrm{CHOI}, \mathrm{K}$. (2002). Lineage analysis of the hemangioblast as defined by FLK1 and SCL expression. Development 129: 5511-5520.

CORBEL, C., SALAUN, J., BELO-DIABANGOUAYA, P. and DIETERLEN-LIEVRE, F. (2007). Hematopoietic potential of the pre-fusion allantois. Dev Bio/301: 478488.

CUMANO, A., FERRAZ, J., KLAINE, M., DI SANTO, J. and GODIN, I. (2001). Intraembryonic, but Not Yolk Sac Hematopoietic Precursors, Isolated before Circulation, Provide Long-Term Multilineage Reconstitution. Immunity 15: 477485.

D'AMOUR, K.A., BANG, A.G., ELIAZER, S., KELLY, O.G., AGULNICK, A.D., SMART, N.G., MOORMAN, M.A., KROON, E., CARPENTER, M.K. and BAETGE, E.E. (2006). Production of pancreatic hormone-expressing endocrine cells from human embryonic stem cells. Nat Biotechno/24: 1392-1401.

D'SOUZA, S.L., ELEFANTY, A.G. and KELLER, G. (2005). SCL/Tal-1 is essential for hematopoietic commitment of the hemangioblast but not for its development. Blood 105: 3862-3870.

DAVIDSON, A.J., ERNST, P., WANG, Y., DEKENS, M.P., KINGSLEY, P.D., PALIS, J., KORSMEYER, S.J., DALEY, G.Q. and ZON, L.I. (2003). cdx4 mutants fail to specify blood progenitors and can be rescued by multiple hox genes. Nature 425: 300-306.

DAVIDSON, A.J. and ZON, L.I. (2006). The caudal-related homeobox genes cdx1a and cdx4 act redundantly to regulate hox gene expression and the formation of putative hematopoietic stem cells during zebrafish embryogenesis. Dev Biol 292: 506-518.

DAVIDSON, E.H. and ERWIN, D.H. (2006). Gene regulatory networks and the evolution of animal body plans. Science 311: 796-800.

DAVIS, R.P., NG, E.S., COSTA, M., MOSSMAN, A.K., SOURRIS, K., ELEFANTY, A.G. and STANLEY, E.G. (2008). Targeting a GFP reporter gene to the MIXL1 locus of human embryonic stem cells identifies human primitive streak-like cells and enables isolation of primitive hematopoietic precursors. Blood111: 18761884.

DE BRUIJN, M.F., MA, X., ROBIN, C., OTTERSBACH, K., SANCHEZ, M.J. and DZIERZAK, E. (2002). Hematopoietic stem cells localize to the endothelial cell layer in the midgestation mouse aorta. Immunity 16: 673-683.

DE BRUIJN, M.F., SPECK, N.A., PEETERS, M.C. and DZIERZAK, E. (2000). Definitive hematopoietic stem cells first develop within the major arterial regions of the mouse embryo. EMBO J19: 2465-2474.

DOWNS, K.M. (2002). Early placental ontogeny in the mouse. Placenta23: 116-31.

DZIERZAK, E. and SPECK, N.A. (2008). Of lineage and legacy: the development of mammalian hematopoietic stem cells. Nat Immuno/9: 129-136.

EILKEN, H.M., NISHIKAWA, S. and SCHROEDER, T. (2009). Continuous singlecell imaging of blood generation from haemogenic endothelium. Nature 457: 896-900.
EMA, M., TAKAHASHI, S. and ROSSANT, J. (2006). Deletion of the selection cassette, but not cis-acting elements, in targeted Flk1-lacZ allele reveals Flk1 expression in multipotent mesodermal progenitors. Blood 107: 111-117.

EVANS, M.J. and KAUFMAN, M.H. (1981). Establishment in culture of pluripotential cells from mouse embryos. Nature 292: 154-156.

FALOON, P., ARENTSON, E., KAZAROV, A., DENG, C.X., PORCHER, C., ORKIN, S. and CHOI, K. (2000). Basic fibroblast growth factor positively regulates hematopoietic development. Development 127: 1931-1941.

FEHLING, H.J., LACAUD, G., KUBO, A., KENNEDY, M., ROBERTSON, S., KELLER, G. and KOUSKOFF, V. (2003). Tracking mesoderm induction and its specification to the hemangioblast during embryonic stem cell differentiation. Development 130: 4217-4227.

FERKOWICZ, M.J., STARR, M., XIE, X., LI, W., JOHNSON, S.A., SHELLEY, W.C., MORRISON, P.R. and YODER, M.C. (2003). CD41 expression defines the onset of primitive and definitive hematopoiesis in the murine embryo. Development 130: 4393-4403.

FERKOWICZ, M.J. and YODER, M.C. (2005). Blood island formation: longstanding observations and modern interpretations. Exp Hemato/33: 1041-1047.

FERRARA, N., CARVER-MOORE, K., CHEN, H., DOWD, M., LU, L., O'SHEA, K.S., POWELL-BRAXTON, L., HILLAN, K.J. and MOORE, M.W. (1996). Heterozygous embryonic lethality induced by targeted inactivation of the VEFG gene. Nature 380: 439-442.

FONG, G.H., KLINGENSMITH, J., WOOD, C.R., ROSSANT, J. and BREITMAN, M.L. (1996). Regulation of flt-1 expression during mouse embryogenesis suggests a role in the establishment of vascular endothelium. Dev Dyn207: 110.

FURUTA, C., EMA, H., TAKAYANAGI, S., OGAERI, T., OKAMURA, D., MATSUI, Y. and NAKAUCHI, H. (2006). Discordant developmental waves of angioblasts and hemangioblasts in the early gastrulating mouse embryo. Development 133: 2771-2779.

GADUE, P., HUBER, T.L., PADDISON, P.J. and KELLER, G.M. (2006). Wnt and TGF-beta signaling are required for the induction of an in vitromodel of primitive streak formation using embryonic stem cells. Proc Natl Acad Sci USA 103 16806-16811.

GARCIA-PORRERO, J.A., MANAIA, A., JIMENO, J., LASKY, L.L., DIETERLENLIEVRE, F. and GODIN, I.E. (1998). Antigenic profiles of endothelial and hemopoietic lineages in murine intraembryonic hemogenic sites. Dev Comp Immuno/22: 303-319.

GEKAS, C., DIETERLEN-LIEVRE, F., ORKIN, S.H. and MIKKOLA, H.K. (2005) The placenta is a niche for hematopoietic stem cells. Dev Cel/8: 365-375.

GODIN, I., GARCIA-PORRERO, J.A., DIETERLEN-LIEVRE, F. and CUMANO, A. (1999). Stem cell emergence and hemopoietic activity are incompatible in mouse intraembryonic sites. J Exp Med 190: 43-52.

GUO, Y., CHAN, R., RAMSEY, H., LI, W., XIE, X., SHELLEY, W.C., MARTINEZBARBERA, J.P., BORT, B., ZARET, K., YODER, M. et al. (2003). The homeoprotein Hex is required for hemangioblast differentiation. Blood 102: 2428-2435.

HART, A., MELET, F., GROSSFELD, P., CHIEN, K., JONES, C., TUNNACLIFFE, A., FAVIER, R. and BERNSTEIN, A. (2000). Fli-1 is required for murine vascular and megakaryocytic development and is hemizygously deleted in patients with thrombocytopenia. Immunity 13: 167-177.

HINMAN, V.F., NGUYEN, A.T., CAMERON, R.A. and DAVIDSON, E.H. (2003). Developmental gene regulatory network architecture across 500 million years of echinoderm evolution. Proc Nat/ Acad Sci USA 100: 13356-13361.

HUANGFU, D., OSAFUNE, K., MAEHR, R., GUO, W., EIJKELENBOOM, A., CHEN, S., MUHLESTEIN, W. and MELTON, D.A. (2008). Induction of pluripotent stem cells from primary human fibroblasts with only Oct4 and Sox2. Nat Biotechno/26: 1269-1275.

HUBER, T.L., KOUSKOFF, V., FEHLING, H.J., PALIS, J. and KELLER, G. (2004). Haemangioblast commitment is initiated in the primitive streak of the mouse embryo. Nature 432: 625-630.

ISMAILOGLU, I., YEAMANS, G., DALEY, G.Q., PERLINGEIRO, R.C. and KYBA, M. (2008). Mesodermal patterning activity of SCL. Exp Hematol. 36: 1593-1603.

JAENISCH, R. and YOUNG, R. (2008). Stem cells, the molecular circuitry of pluripotency and nuclear reprogramming. Cel/132: 567-582.

JAFFREDO, T., NOTTINGHAM, W., LIDDIARD, K., BOLLEROT, K., POUGET, C. 
and DE BRUIJN, M. (2005). From hemangioblast to hematopoietic stem cell: an endothelial connection? Exp Hemato/33: 1029-1040.

JOHANSSON, B.M. and WILES, M.V. (1995). Evidence for involvement of activin $A$ and bone morphogenetic protein 4 in mammalian mesoderm and hematopoietic development. Mol Cel/ Bio/15: 141-151.

JOHNSON, G.R. and MOORE, M.A. (1975). Role of stem cell migration in initiation of mouse foetal liver haemopoiesis. Nature 258: 726-728.

JOKUBAITIS, V.J., SINKA, L., DRIESSEN, R., WHITTY, G., HAYLOCK, D.N., BERTONCELLO, I., SMITH, I., PEAULT, B., TAVIAN, M. and SIMMONS, P.J. (2008). Angiotensin-converting enzyme (CD143) marks hematopoietic stem cells in human embryonic, fetal, and adult hematopoietic tissues. Blood 111: 4055-4063.

KABRUN, N., BUHRING, H.J., CHOI, K., ULLRICH, A., RISAU, W. and KELLER, G. (1997). Flk-1 expression defines a population of early embryonic hematopoietic precursors. Development 124: 2039-2048.

KADOWAKI, T., WILDER, E., KLINGENSMITH, J., ZACHARY, K. and PERRIMON, N. (1996). The segment polarity gene porcupine encodes a putative multitransmembrane protein involved in Wingless processing. Genes Dev 10: 3116-3128.

KALLIANPUR, A.R., JORDAN, J.E. and BRANDT, S.J. (1994). The SCL/TAL-1 gene is expressed in progenitors of both the hematopoietic and vascular systems during embryogenesis. Blood 83: 1200-1208.

KENNEDY, M., D'SOUZA, S.L., LYNCH-KATTMAN, M., SCHWANTZ, S. and KELLER, G. (2007). Development of the hemangioblast defines the onset of hematopoiesis in human ES cell differentiation cultures. Blood109: 2679-2687.

KENNEDY, M., FIRPO, M., CHOI, K., WALL, C., ROBERTSON, S., KABRUN, N. and KELLER, G. (1997). A common precursor for primitive and definitive hematopoiesis. Nature 386: 488-493.

KINDER, S.J., TSANG, T.E., QUINLAN, G.A., HADJANTONAKIS, A.K., NAGY, A. and TAM, P.P. (1999). The orderly allocation of mesodermal cells to the extraembryonic structures and the anteroposterior axis during gastrulation of the mouse embryo. Development 126: 4691-4701.

KISHIMOTO, Y., LEE, K.H., ZON, L., HAMMERSCHMIDT, M. and SCHULTEMERKER, S. (1997). The molecular nature of zebrafish swirl: BMP2 function is essential during early dorsoventral patterning. Development 124: 4457-4466.

KUBO, A., CHEN, V., KENNEDY, M., ZAHRADKA, E., DALEY, G.Q. and KELLER, G. (2005). The homeobox gene HEX regulates proliferation and differentiation of hemangioblasts and endothelial cells during ES cell differentiation. Blood 105: 4590-4597.

KUNATH, T., SABA-EL-LEIL, M.K., ALMOUSAILLEAKH, M., WRAY, J., MELOCHE, S. and SMITH, A. (2007). FGF stimulation of the Erk1/2 signalling cascade triggers transition of pluripotent embryonic stem cells from self-renewal to lineage commitment. Development 134: 2895-2902.

KYBA, M., PERLINGEIRO, R.C. and DALEY, G.Q. (2002). HoxB4 confers definitive lymphoid-myeloid engraftment potential on embryonic stem cell and yolk sac hematopoietic progenitors. Cel/109: 29-37.

LACAUD, G., GORE, L., KENNEDY, M., KOUSKOFF, V., KINGSLEY, P., HOGAN, C., CARLSSON, L., SPECK, N., PALIS, J. and KELLER, G. (2002). Runx1 is essential for hematopoietic commitment at the hemangioblast stage of development in vitro. Blood 100: 458-466.

LANCRIN, C., SROCZYNSKA, P., STEPHENSON, C., ALLEN, T., KOUSKOFF, V. and LACAUD, G. (2009). The haemangioblast generates haematopoietic cells through a haemogenic endothelium stage. Nature 457: 892-895.

LAWSON, K.A., MENESES, J.J. and PEDERSEN, R.A. (1991). Clonal analysis of epiblast fate during germ layer formation in the mouse embryo. Development 113: 891-911.

LEDRAN, M.H., KRASSOWSKA, A., ARMSTRONG, L., DIMMICK, I., RENSTROM, J., LANG, R., YUNG, S., SANTIBANEZ-COREF, M., DZIERZAK, E., STOJKOVIC, M. et al. (2008). Efficient hematopoietic differentiation of human embryonic stem cells on stromal cells derived from hematopoietic niches. Cell Stem Cel/3: 85-98.

LEE, D., PARK, C., LEE, H., LUGUS, J.J., KIM, S.H., ARENTSON, E., CHUNG, Y.S., GOMEZ, G., KYBA, M., LIN, S. et al. (2008). ER71 acts downstream of BMP, Notch, and Wnt signaling in blood and vessel progenitor specification. Cel/ Stem Cel/2: 497-507.

LENGERKE, C., SCHMITT, S., BOWMAN, T.V., JANG, I.H., MAOUCHE-CHRETIEN,
L., MCKINNEY-FREEMAN, S., DAVIDSON, A.J., HAMMERSCHMIDT, M., RENTZSCH, F., GREEN, J.B. etal. (2008). BMP and Wnt specify hematopoietic fate by activation of the Cdx-Hox pathway. Cell Stem Cel/2: 72-82.

LIU, F., WALMSLEY, M., RODAWAY, A. and PATIENT, R. (2008). Fli1 acts at the top of the transcriptional network driving blood and endothelial development. Curr Bio/18: 1234-1240.

LOHMANN, F. and BIEKER, J.J. (2008). Activation of Eklf expression during hematopoiesis by Gata2 and Smad5 prior to erythroid commitment. Develop ment 135: 2071-2082.

LOHNES, D. (2003). The Cdx1 homeodomain protein: an integrator of posterior signaling in the mouse. Bioessays 25: 971-980.

LU, S.J., FENG, Q., CABALLERO, S., CHEN, Y., MOORE, M.A., GRANT, M.B. and LANZA, R. (2007). Generation of functional hemangioblasts from human embryonic stem cells. Nat Methods 4: 501-509.

LUGUS, J.J., CHUNG, Y.S., MILLS, J.C., KIM, S.I., GRASS, J., KYBA, M., DOHERTY, J.M., BRESNICK, E.H. and CHOI, K. (2007). GATA2 functions at multiple steps in hemangioblast development and differentiation. Development 134: 393-405

LUGUS, J.J., PARK, C., MA, Y.D. and CHOI, K. (2008). Both primitive and definitive blood cells are derived from Flk-1+ mesoderm. Blood. 113: 563-566.

LUX, C.T., YOSHIMOTO, M., MCGRATH, K., CONWAY, S.J., PALIS, J. and YODER, M.C. (2008). All primitive and definitive hematopoietic progenitor cells emerging before $\mathrm{E} 10$ in the mouse embryo are products of the yolk sac. Blood 111: 3435-3438.

MAENO, M., ONG, R.C., SUZUKI, A., UENO, N. and KUNG, H.-F. (1994). A truncated bone morphogenetic protein 4 receptor alters the fate of ventra mesoderm to dorsal mesoderm: Roles of animal pole tissue in the development of ventral mesoderm. Proc. Natl. Acad. Sci. USA 91: 10260-10264.

MARTIN, G.R. (1981). Isolation of a pluripotent cell line from early mouse embryos cultured in medium conditioned by teratocarcinoma stem cells. Proc Nat/ Acad SCi USA 78: 7634-7638.

MCKINNEY-FREEMAN, S.L., LENGERKE, C., JANG, I.H., SCHMITT, S., WANG Y., PHILITAS, M., SHEA, J. and DALEY, G.Q. (2008). Modulation of murine embryonic stem cell-derived CD41+c-kit+ hematopoietic progenitors by ectopic expression of Cdx genes. Blood111: 4944-4953.

MEDVINSKY, A. and DZIERZAK, E. (1996). Definitive Hematopoiesis Is Autonomously Initiated by the AGM Region. Cel/86: 897-906.

MICCHELLI, C.A., THE, I., SELVA, E., MOGILA, V. and PERRIMON, N. (2002) Rasp, a putative transmembrane acyltransferase, is required for Hedgehog signaling. Development 129: 843-851.

MILLAUER, B., WIZIGMANN-VOOS, S., SCHNÜRCH, H., MARTINEZ, R., MØLLER N.P.H., RISAU, W. and ULLRICH, A. (1993). High affinity VEGF binding and developmental expression suggest Flk-1 as a major regulator of vasculogenesis and angiogenesis. Cel/72: 835-846.

MOORE, K.A., EMA, H. and LEMISCHKA, I.R. (1997). In vitro maintenance of highly purified, transplantable hematopoietic stem cells. Blood89: 4337-4347.

MOORE, M.A. and METCALF, D. (1970). Ontogeny of the haemopoietic system: yolk sac origin of in vivoand in vitrocolony forming cells in the developing mouse embryo. Br J Haemato/ 18: 279-296.

MULLER, A.M., MEDVINSKY, A., STROUBOULIS, J., GROSVELD, F. and DZIERZAK, E. (1994). Development of hematopoietic stem cell activity in the mouse embryo. Immunity 1: 291-301.

MULLINS, M.C., HAMMERSCHMIDT, M., KANE, D.A., ODENTHAL, J., BRAND, M., VAN EEDEN, F.J., FURUTANI-SEIKI, M., GRANATO, M., HAFFTER, P., HEISENBERG, C.P. et al. (1996). Genes establishing dorsoventral pattern formation in the zebrafish embryo: the ventral specifying genes. Development 123: 81-93.

MURRY, C.E. and KELLER, G. (2008). Differentiation of embryonic stem cells to clinically relevant populations: lessons from embryonic development. Cel/132 661-680.

NAKANO, T., KODAMA, H. and HONJO, T. (1994). Generation of lymphohematopoietic cells from embryonic stem cells in culture. Science 265 1098-1101.

NG, E.S., AZZOLA, L., SOURRIS, K., ROBB, L., STANLEY, E.G. and ELEFANTY, A.G. (2005). The primitive streak gene Mixl1 is required for efficient haematopoiesis and BMP4-induced ventral mesoderm patterning in differenti- 
ating ES cells. Development 132: 873-884.

NISHIKAWA, S.-I., NISHIKAWA, S., KAWAMOTO, H., YOSHIDA, H., KIZUMOTO, M., KATAOKA, H. and KATSURA, Y. (1998a). In vitro generation of lymphohematopoietic cells from endothelial cells purified from murine embryos. Immunity 8: 761-768.

NISHIKAWA, S.I., NISHIKAWA, S., HIRASHIMA, M., MATSUYOSHI, N. and KODAMA, H. (1998b). Progressive lineage analysis by cell sorting and culture identifies Flk+VE-cadherin+ cells at a diverging point of endothelial hematopoietic lineages. Development 125: 1747-1757.

NORTH, T., GU, T.L., STACY, T., WANG, Q., HOWARD, L., BINDER, M., MARINPADILLA, M. and SPECK, N.A. (1999). Cbfa2 is required for the formation of intra-aortic hematopoietic clusters. Development 126: 2563-2575.

NOSTRO, M.C., CHENG, X., KELLER, G.M. and GADUE, P. (2008). Wnt, activin, and BMP signaling regulate distinct stages in the developmental pathway from embryonic stem cells to blood. Cel/ Stem Cel/2: 60-71.

OKITA, K., ICHISAKA, T. and YAMANAKA, S. (2007). Generation of germlinecompetent induced pluripotent stem cells. Nature 448: 313-317.

OLSEN, A.L., STACHURA, D.L. and WEISS, M.J. (2006). Designer blood: creating hematopoietic lineages from embryonic stem cells. Blood 107: 1265-1275.

OOSTENDORP, R.A., HARVEY, K.N., KUSADASI, N., DE BRUIJN, M.F., SARIS, C., PLOEMACHER, R.E., MEDVINSKY, A.L. and DZIERZAK, E.A. (2002). Stromal cell lines from mouse aorta-gonads-mesonephros subregions are potent supporters of hematopoietic stem cell activity. Blood99: 1183-1189.

ORLOVSKAYA, I., SCHRAUFSTATTER, I., LORING, J. and KHALDOYANIDI, S. (2008). Hematopoietic differentiation of embryonic stem cells. Methods 45: 159167.

OTTERSBACH, K. and DZIERZAK, E. (2005). The murine placenta contains hematopoietic stem cells within the vascular labyrinth region. Dev Cel/8: 377387.

PALIS, J., ROBERSTON, S., KENNEDY, M., WALL, C. and KELLER, G. (1999). Development of erythroid and myeloid progenitors in the yolk sac and embryo proper of the mouse. Development 126: 5073-5084.

PARK, C., AFRIKANOVA, I., CHUNG, Y.S., ZHANG, W.J., ARENTSON, E., FONG $\mathrm{GH}, \mathrm{G}$., ROSENDAHL, A. and CHOI, K. (2004). A hierarchical order of factors in the generation of FLK1 - and SCL-expressing hematopoietic and endothelial progenitors from embryonic stem cells. Development 131: 2749-2762.

PARK, C., LUGUS, J.J. and CHOI, K. (2005). Stepwise commitment from embryonic stem to hematopoietic and endothelial cells. Curr Top Dev Bio/66: 1-36.

PARK, I.H., ZHAO, R., WEST, J.A., YABUUCHI, A., HUO, H., INCE, T.A., LEROU, P.H., LENSCH, M.W. and DALEY, G.Q. (2008). Reprogramming of human somatic cells to pluripotency with defined factors. Nature 451: 141-146.

PEARSON, S., SROCZYNSKA, P., LACAUD, G. and KOUSKOFF, V. (2008). The stepwise specification of embryonic stem cells to hematopoietic fate is driven by sequential exposure to Bmp4, activin A, bFGF and VEGF. Development 135: 1525-1535.

PERLINGEIRO, R.C. (2007). Endoglin is required for hemangioblast and early hematopoietic development. Development 134: 3041-3048.

PICK, M., AZZOLA, L., MOSSMAN, A., STANLEY, E.G. and ELEFANTY, A.G. (2007). Differentiation of human embryonic stem cells in serum-free medium reveals distinct roles for bone morphogenetic protein 4 , vascular endothelial growth factor, stem cell factor, and fibroblast growth factor 2 in hematopoiesis. Stem Cells 25: 2206-2214.

PIMANDA, J.E., DONALDSON, I.J., DE BRUIJN, M.F., KINSTON, S., KNEZEVIC, K., HUCKLE, L., PILTZ, S., LANDRY, J.R., GREEN, A.R., TANNAHILL, D. etal (2007a). The SCL transcriptional network and BMP signaling pathway interact to regulate RUNX1 activity. Proc Natl Acad Sci USA 104: 840-845.

PIMANDA, J.E., OTTERSBACH, K., KNEZEVIC, K., KINSTON, S., CHAN, W.Y., WILSON, N.K., LANDRY, J.R., WOOD, A.D., KOLB-KOKOCINSKI, A., GREEN, A.R. etal. (2007b). Gata2, Fli1, and Scl form a recursively wired gene-regulatory circuit during early hematopoietic development. Proc Natl Acad Sci USA 104: $17692-17697$.

QI, X., LI, T.G., HAO, J., HU, J., WANG, J., SIMMONS, H., MIURA, S., MISHINA, Y. and ZHAO, G.Q. (2004). BMP4 supports self-renewal of embryonic stem cells by inhibiting mitogen-activated protein kinase pathways. Proc Nat/ Acad $\mathrm{SCI}$ USA 101: 6027-6032.

RE'EM-KALMA, Y., LAMB, T. and FRANK, D. (1995). Competition between noggin and bone morphogenetic protein 4 activities may regulate dorsalization during Xenopus development. Proc. Natl. Acad. Sci. USA 92: 12141-12145.

RHODES, K.E., GEKAS, C., WANG, Y., LUX, C.T., FRANCIS, C.S., CHAN, D.N., CONWAY, S., ORKIN, S.H., YODER, M.C. and MIKKOLA, H.K. (2008). The emergence of hematopoietic stem cells is initiated in the placental vasculature in the absence of circulation. Cel/ Stem Cel/2: 252-263.

SABIN, F.R. (1920). Studies on the origin of blood vessels and of red corpuscles as seen in the living blastoderm of the chick during the second day of incubation. Contrib. Embryol. 9: 213-262.

SAKURAI, H., ERA, T., JAKT, L.M., OKADA, M., NAKAI, S. and NISHIKAWA, S. (2006). In vitro modeling of paraxial and lateral mesoderm differentiation reveals early reversibility. Stem Cel/s 24: 575-586.

SCHMITT, T.M., DE POOTER, R.F., GRONSKI, M.A., CHO, S.K., OHASHI, P.S and ZUNIGA-PFLUCKER, J.C. (2004). Induction of T cell development and establishment of $\mathrm{T}$ cell competence from embryonic stem cells differentiated in vitro. Nat Immuno/5: 410-417.

SHALABY, F., HO, J., STANFORD, W.L., FISCHER, K.D., SCHUH, A.C. SCHWARTZ, L., BERNSTEIN, A. and ROSSANT, J. (1997). A requirement for Flk1 in primitive and definitive hematopoiesis and vasculogenesis. Cel/89: 981 90.

SHALABY, F., ROSSANT, J., YAMAGUCHI, T.P., GERTSENSTEIN, M., WU, X.F., BREITMAN, M.L. and SCHUH, A.C. (1995). Failure of blood-island formation and vasculogenesis in Flk-1 deficient mice. Nature 376: 62-66.

SHI, Y., DESPONTS, C., DO, J.T., HAHM, H.S., SCHOLER, H.R. and DING, S (2008). Induction of pluripotent stem cells from mouse embryonic fibroblasts by Oct4 and Klf4 with small-molecule compounds. Cel/ Stem Cel/3: 568-574.

SMITH, A.G., HEATH, J.K., DONALDSON, D.D., WONG, G.G., MOREAU, J., STAHL, M. and ROGERS, D. (1988). Inhibition of pluripotential embryonic stem cell differentiation by purified polypeptides. Nature 336: 688-690.

SPYROPOULOS, D.D., PHARR, P.N., LAVENBURG, K.R., JACKERS, P., PAPAS T.S., OGAWA, M. and WATSON, D.K. (2000). Hemorrhage, impaired hematopoiesis, and lethality in mouse embryos carrying a targeted disruption of the Fli1 transcription factor. Mol Cel/ Bio/20: 5643-5652.

STANTON, L.W. and BAKRE, M.M. (2007). Genomic and proteomic characterization of embryonic stem cells. Curr Opin Chem Bio/11: 399-404.

SUBRAMANIAN, V., MEYER, B.I. and GRUSS, P. (1995). Disruption of the murine homeobox gene $\mathrm{Cdx} 1$ affects axial skeletal identities by altering the mesodermal expression domains of Hox genes. Cel/83: 641-653.

SUMI, T., TSUNEYOSHI, N., NAKATSUJI, N. and SUEMORI, H. (2008). Defining early lineage specification of human embryonic stem cells by the orchestrated balance of canonical Wnt/beta-catenin, Activin/Nodal and BMP signaling. Development 135: 2969-2979.

TADA, S., ERA, T., FURUSAWA, C., SAKURAI, H., NISHIKAWA, S., KINOSHITA M., NAKAO, K. and CHIBA, T. (2005). Characterization of mesendoderm: diverging point of the definitive endoderm and mesoderm in embryonic stem cell differentiation culture. Development 132: 4363-4374.

TAKAHASHI, K., TANABE, K., OHNUKI, M., NARITA, M., ICHISAKA, T., TOMODA K. and YAMANAKA, S. (2007). Induction of pluripotent stem cells from adult human fibroblasts by defined factors. Ce//131: 861-872.

TAKAHASHI, K. and YAMANAKA, S. (2006). Induction of pluripotent stem cells from mouse embryonic and adult fibroblast cultures by defined factors. Ce//126: 663-676

TAKAKURA, N., YOSHIDA, H., OGURA, Y., KATAOKA, H. and NISHIKAWA, S. (1997). PDGFR alpha expression during mouse embryogenesis: immunolocalization analyzed by whole-mount immunohistostaining using the monoclonal anti-mouse PDGFR alpha antibody APA5. J Histochem Cytochem 45: 883-893.

TAOUDI, S., GONNEAU, C., MOORE, K., SHERIDAN, J.M., BLACKBURN, C.C., TAYLOR, E. and MEDVINSKY, A. (2008). Extensive hematopoietic stem cel generation in the AGM region via maturation of VE-cadherin+CD45+ predefinitive HSCs. Cel/ Stem Cel/3: 99-108.

TIAN, X. and KAUFMAN, D.S. (2008). Differentiation of embryonic stem cells towards hematopoietic cells: progress and pitfalls. Curr Opin Hemato/15: 312 318.

TIAN, X., MORRIS, J.K., LINEHAN, J.L. and KAUFMAN, D.S. (2004). Cytokine requirements differ for stroma and embryoid body-mediated hematopoiesis from human embryonic stem cells. Exp Hemato/32: 1000-1009. 
TIAN, X., WOLL, P.S., MORRIS, J.K., LINEHAN, J.L. and KAUFMAN, D.S. (2006). Hematopoietic engraftment of human embryonic stem cell-derived cells is regulated by recipient innate immunity. Stem Cells 24: 1370-1380.

UENO, H. and WEISSMAN, I.L. (2006). Clonal analysis of mouse development reveals a polyclonal origin for yolk sac blood islands. Dev Ce//11: 519-533.

VAN DEN AKKER, E., FORLANI, S., CHAWENGSAKSOPHAK, K., DE GRAAFF W., BECK, F., MEYER, B.I. and DESCHAMPS, J. (2002). Cdx1 and Cdx2 have overlapping functions in anteroposterior patterning and posterior axis elongation. Development 129: 2181-2193.

VAN NES, J., DE GRAAFF, W., LEBRIN, F., GERHARD, M., BECK, F. and DESCHAMPS, J. (2006). The Cdx4 mutation affects axial development and reveals an essential role of $\mathrm{Cdx}$ genes in the ontogenesis of the placental labyrinth in mice. Development 133: 419-428.

WANG, C., FALOON, P.W., TAN, Z., LV, Y., ZHANG, P., GE, Y., DENG, H. and XIONG, J.W. (2007a). Mouse lysocardiolipin acyltransferase controls the development of hematopoietic and endothelial lineages during in vitro embryonic stem-cell differentiation. Blood110: 3601-3609.

WANG, J., THEUNISSEN, T.W. and ORKIN, S.H. (2007b). Site-directed, virus-free, and inducible RNAi in embryonic stem cells. Proc Natl Acad Sci USA 104: 20850-20855.

WANG, L., LI, L., SHOJAEI, F., LEVAC, K., CERDAN, C., MENENDEZ, P., MARTIN, T., ROULEAU, A. and BHATIA, M. (2004). Endothelial and hematopoietic cell fate of human embryonic stem cells originates from primitive endothelium with hemangioblastic properties. Immunity 21: 31-41.

WANG, L., MENENDEZ, P., SHOJAEI, F., LI, L., MAZURIER, F., DICK, J.E., CERDAN, C., LEVAC, K. and BHATIA, M. (2005a). Generation of hematopoietic repopulating cells from human embryonic stem cells independent of ectopic HOXB4 expression. J Exp Med201: 1603-1614.

WANG, Y., YABUUCHI, A., MCKINNEY-FREEMAN, S., DUCHARME, D.M., RAY, M.K., CHAWENGSAKSOPHAK, K., ARCHER, T.K. and DALEY, G.Q. (2008). $\mathrm{Cdx}$ gene deficiency compromises embryonic hematopoiesis in the mouse. Proc Nat/ Acad Sci USA 105: 7756-7761.

WANG, Y., YATES, F., NAVEIRAS, O., ERNST, P. and DALEY, G.Q. (2005b). Embryonic stem cell-derived hematopoietic stem cells. Proc Nat/Acad Sci USA 102: 19081-19086.

WATT, S.M., GSCHMEISSNER, S.E. and BATES, P.A. (1995). PECAM-1: its expression and function as a cell adhesion molecule on hemopoietic and endothelial cells. Leuk Lymphoma 17: 229-244.

WEISEL, K.C., GAO, Y., SHIEH, J.H. and MOORE, M.A. (2006). Stromal cell lines from the aorta-gonado-mesonephros region are potent supporters of murine and human hematopoiesis. Exp Hemato/34: 1505-1516.

WERNIG, M., MEISSNER, A., FOREMAN, R., BRAMBRINK, T., KU, M., HOCHEDLINGER, K., BERNSTEIN, B.E. and JAENISCH, R. (2007). In vitro reprogramming of fibroblasts into a pluripotent ES-cell-like state. Nature 448: 318-324.

WILLIAMS, R.L., HILTON, D.J., PEASE, S., WILLSON, T.A., STEWART, C.L., GEARING, D.P., WAGNER, E.F., METCALF, D., NICOLA, N.A. and GOUGH, N.M. (1988). Myeloid leukaemia inhibitory factor maintains the developmental potential of embryonic stem cells. Nature 336: 684-687.
XU, M.J., TSUJI, K., UEDA, T., MUKOUYAMA, Y.S., HARA, T., YANG, F.C., EBIHARA, Y., MATSUOKA, S., MANABE, A., KIKUCHI, A. et al. (1998). Stimulation of mouse and human primitive hematopoiesis by murine embryonic aorta-gonad-mesonephros-derived stromal cell lines. Blood92: 2032-2040.

YAMAGUCHI, T.P., DUMONT, D.J., CONLON, R.A., BREITMAN, M.L. and ROSSANT, J. (1993). flk-1, an flt-related receptor tyrosine kinase is an early marker for endothelial cell precursors. Development 118: 489-498.

YING, Q.L., NICHOLS, J., CHAMBERS, I. and SMITH, A. (2003). BMP induction of Id proteins suppresses differentiation and sustains embryonic stem cell selfrenewal in collaboration with STAT3. Ce//115: 281-292.

YING, Q.L., WRAY, J., NICHOLS, J., BATLLE-MORERA, L., DOBLE, B., WOODGETT, J., COHEN, P. and SMITH, A. (2008). The ground state of embryonic stem cell self-renewal. Nature 453: 519-523.

YODER, M.C., HIATT, K., DUTT, P., MUKHERJEE, P., BODINE, D.M. and ORLIC, D. (1997). Characterization of definitive lymphohematopoietic stem cells in the day 9 murine yolk sac. Immunity 7: 335-344.

YOUNG, P.E., BAUMHUETER, S. and LASKY, L.A. (1995). The sialomucin CD34 is expressed on hematopoietic cells and blood vessels during murine development. Blood 85: 96-105.

YU, J., VODYANIK, M.A., SMUGA-OTTO, K., ANTOSIEWICZ-BOURGET, J., FRANE, J.L., TIAN, S., NIE, J., JONSDOTTIR, G.A., RUOTTI, V., STEWART, R. et al. (2007). Induced pluripotent stem cell lines derived from human somatic cells. Science 318: 1917-1920.

ZAFONTE, B.T., LIU, S., LYNCH-KATTMAN, M., TORREGROZA, I., BENVENUTO L., KENNEDY, M., KELLER, G. and EVANS, T. (2007). Smad1 expands the hemangioblast population within a limited developmental window. Blood 109 516-523.

ZAMBIDIS, E.T., PEAULT, B., PARK, T.S., BUNZ, F. and CIVIN, C.I. (2005) Hematopoietic differentiation of human embryonic stem cells progresses through sequential hematoendothelial, primitive, and definitive stages resembling human yolk sac development. Blood 106: 860-870.

ZAMBIDIS, E.T., SOON PARK, T., YU, W., TAM, A., LEVINE, M., YUAN, X. PRYZHKOVA, M. and PEAULT, B. (2008). Expression of angiotensin-converting enzyme (CD143) identifies and regulates primitive hemangioblasts derived from human pluripotent stem cells. Blood112: 3601-3614.

PETERS, A., BURRIDGE, P.W., PRYZHKOVA, M.V., LEVINE, M.A., PARK, T.S. ROXBURY, C., YUAN, X., PÉAULT, B. and ZAMBIDIS, E.T. (2010) Challenges and strategies for generating therapeutic patient-specific hemangioblasts and hematopoietic stem cells from human pluripotent stem cells. Int. J. Dev. Biol. 54 965-990. (doi: 10.1387/ijdb.093043ap)

ZEIGLER, B.M., SUGIYAMA, D., CHEN, M., GUO, Y., DOWNS, K.M. and SPECK, N.A. (2006). The allantois and chorion, when isolated before circulation or chorio-allantoic fusion, have hematopoietic potential. Development 133: 41834192.

ZOVEIN, A.C., HOFMANN, J.J., LYNCH, M., FRENCH, W.J., TURLO, K.A., YANG Y., BECKER, M.S., ZANETTA, L., DEJANA, E., GASSON, J.C. et al. (2008). Fate tracing reveals the endothelial origin of hematopoietic stem cells. Cell Stem Cel/3: 625-636. 


\section{Further Related Reading, published previously in the Int. J. Dev. Biol.}

See our recent Special Issue Placenta edited by Joan S. Hunt and Kent L. Thornburg at: http://www.ijdb.ehu.es/web/contents.php?vol=54\&issue=2-3

Tracing the hemangioblast during embryogenesis: developmental relationships between endothelial and hematopoietic cells

Thierry Jaffredo, Karine Bollerot, Daisuke Sugiyama, Rodolphe Gautier and Cécile Drevon Int. J. Dev. Biol. (2005) 49: 269-277

Of birds and mice: hematopoietic stem cell development

Isabelle Godin and Ana Cumano

Int. J. Dev. Biol. (2005) 49: 251-257

Embryonic development of the human hematopoietic system

Manuela Tavian and Bruno Péault

Int. J. Dev. Biol. (2005) 49: 243-250

Multilineage hematopoietic progenitor activity generated autonomously in the mouse yolk sac: analysis using angiogenesis-defective embryos

Christine Rampon and Philippe Huber

Int. J. Dev. Biol. (2003) 47: 273-280

Pathways in blood and vessel development revealed through zebrafish genetics

Philip S Crosier, Maggie L Kalev-Zylinska, Christopher J Hall, Maria Vega C Flores, Julia A Horsfield and Kathryn E Crosier

Int. J. Dev. Biol. (2002) 46: 493-502

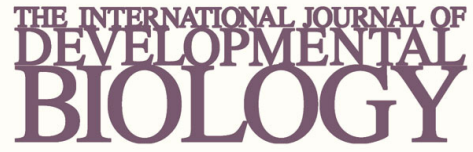

Volume 54 Nos. 6/7 Special Issue
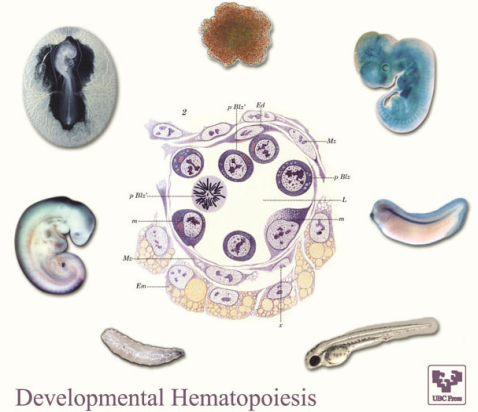

5 yr ISI Impact Factor (2009) $=3.253$

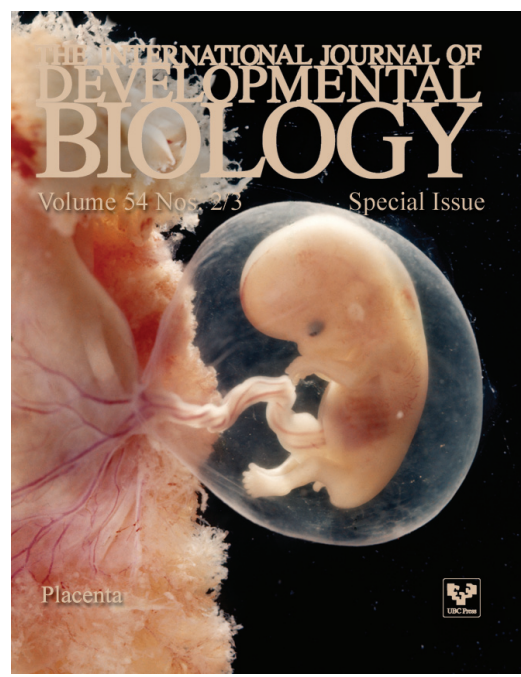

